\title{
ASSOCIATION OF BMI (BODY MASS INDEX) TO HEMOGLOBIN AND RED BLOOD CELL INDICES AMONG ADOLESCENTS.
}

1. MBBS, DCN, MCPS,

M.Phil (Physiology)

Assistant Professor Physiology

Baqai Medical University, Karachi.

2. MBBS,

MCPS (Community Medicine)

Assistant Professor Community

Medicine

Karachi Medical \& Dental College Karachi.

3. MBBS, MCPS, FCPS

Assistant Professor Gyn/Obs Karachi Medical \& Dental College Karachi.

4. MBBS, M.Phil (Histopathology)

Senior Lecturer Pathology

Baqai Medical University, Karachi.

5. MBBS, DCH, MCPS

Lecturer Pathology

Karachi Medical \& Dental College Karach

6. MBBS, M.Phil (Physiology) Chairman and Head Physiology Jinnah Sindh Medical University Karachi.

Correspondence Address:

Dr. Saleem Ullah Abro

Department of Physiology

Baqai Medical University, Karachi.

saleemullahabro41@gmail.com.

Article received on:

07/01/2020

Accepted for publication:

$15 / 04 / 2020$

\section{INTRODUCTION}

World health organization (WHO) describes the health, as a state of being a complete physical, mental and social wellbeing and it is not merely the absence of disease or infirmity in human body. ${ }^{1}$ Human Body composition changes from infancy to adolescence significantly regarding relative and absolute variation in the content or amount of protein, lipid, water and minerals. Adolescence is the stage of human life between the ages of 10-19 years, during which rapid growth spurt occurs in human body which leads to increased nutritional (micronutrients and macronutrients) demand. ${ }^{2}$ The nutritional and health status of human body can be measured by Body Mass Index (BMI) or Quetilet index i-e by assesing height (meters square), weight (kilograms) of an individual. ${ }^{3}$ The Quetilet index or Body Mass Index indicates the amount of body tissue masses of human body; these are bones, muscles, and fats. The Quetilet index or Body Mass Index is a simple, inexpensive, and non-invasive method of measurement of body fat (BF) in human body. Body fat (BF) is used in the human body as the source of energy, heat insulation and shock absorption. If excessive fat is deposited in the human body, which ultimately leads to hyperlipidemia or overweight or obesity. So, it is considered as dangerous to human life, which ultimately leads to future morbidity and death. Excessive fat deposition is due to decreased physical activity or lack of activity or increased food intake or increased caloric intake. ${ }^{4}$ According to WHO; overall, $13 \%$ of individuals are obese or having high BMI in the world, which is round about 0.65 billion individuals. ${ }^{5}$ In Pakistan, $5.4 \%$ (7.2 million people) of the total adult population is having the high BMI or having 
the obesity, so our country is ranked $20^{\text {th }}$ in whole world. ${ }^{6}$ Increased body fat or increased adipose tissue is responsible for development of high blood pressure (hypertension), diabetes mellitus (DM) or metabolic syndrome (MS), cardiovascular diseases (CVD), respiratory diseases and it also affects iron metabolism. High BMI or obesity is associated with subclinical inflammation that leads to development of anemia. ${ }^{7}$ Anemia (decreased $\mathrm{Hb} \%$ concentration below normal level or decreased erythrocyte count below normal level) is a global problem and it occurs more in the developing countries. It occurs due to dysfunction in the production of erythrocytes (erythropoiesis), recycling and regulation of erythrocytes or red blood cells (RBCs). ${ }^{8}$ Obesity or high BMI and anemia (iron deficiency) are two forms of the most commonly prevalent nutritional disorders in whole world. Among nutrients, iron (micronutrients) plays a vital role in $\mathrm{Hb} \%$ synthesis, oxidative metabolism (anabolism and catabolism), and energy or ATP production. It affects the cognitive development and behavior, energy or ATP metabolism, immune system, bone health, and work capacity or work performance in humans. ${ }^{9}$ Red blood cells (RBCs) indices are used for assessment of physical characteristic of the erythrocytes or red blood cells (RBCs) and also used for the diagnosis of anemia and its type (microcytic or macrocytic anemia). It includes calculated values of Mean corpuscular hemoglobin $(\mathrm{MCH})$, Mean corpuscular hemoglobin concentration (MCHC), Mean Corpuscular Volume (MCV). ${ }^{8}$ The association $\mathrm{b} / \mathrm{w}$ high BMI or obesity and anemia should be further workup as both are affecting the health status of human body. The aim and objective of this study was to evaluate the association of body mass index (BMI) to hemoglobin \& red blood cell indices (mean corpuscular volume, mean corpuscular hemoglobin, mean corpuscular hemoglobin concentration, red cell distribution width) among adolescent.

\section{MATERIAL \& METHODS}

This is a Descriptive Cross-Sectional study. This study was conducted in department of Physiology, in Baqai Medical University (BMU) Karachi.
This study was done over a period of six months from February 2017 to August 2017.

500 adolescent's students of MBBS, BDS and DPT classes were included. It was calculated with confidence level of $95 \%$ and error of margin is $5 \%$.

The sampling technique used was Non probability purposive.

\section{Inclusion Criteria}

Those students of MBBS, BDS and DPT classes were Healthy and interested in research and had a written or informed consent, were recruited in this study.

\section{Exclusion Criteria}

Students having history of $(\mathrm{H} / \mathrm{O})$ thalassemia major or monor, $\mathrm{H} / \mathrm{O}$ intake of vitamin $\mathrm{B} 12$, folate and iron therapy, $\mathrm{H} / \mathrm{O}$ blood transfusion of packed cells or whole blood or Blood donation in last six months, $\mathrm{H} / \mathrm{O}$ perianal itching or passing worms in stools, $\mathrm{H} / \mathrm{O}$ malabsorption or malnutrition disorders and $\mathrm{H} / \mathrm{O}$ surgery (lleal) leading to deficiency of vitamin B12 (macrocytic anemia).

It was started after taking ethical review board (ERB) from Baqai Medical University Karachi. The written or informed consent were obtained from every enrolled student before start of participation in a research with briefing the research procedure. Enrolled students data were gathered with the help of pre-tested or structural questionnaire. Five hundred (500) blood samples were collected from participants or adolescent's students. All students underwent hematological or laboratorial investigation. Three millimeter (3cc) of blood had been collected in a tube (CP bottle) containing anticoagulant: ethylene diamine tetra acetic acid (EDTA). Complete Blood Count (CBC) was performed by Sysmex (XS1000i) automated flow meter within minutes of collection. Complete Picture (CP) was performed as to assess and record hemoglobin ( $\mathrm{Hb} \%)$ and red blood cell indices (MCV,MCH,MCHC) levels. Red blood cells (RBCs) indices were calculated $(\mathrm{MCH}, \mathrm{MCHC} \& \mathrm{MCV})$ by using different formulas. Mean corpuscular hemoglobin $(\mathrm{MCH})$ is calculated by Hemoglobin (Hb\%) X 10/R.B.C 
and is expressed in picogram. Mean corpuscular hemoglobin concentration $(\mathrm{MCHC})$ is calculated from Hemoglobin (Hb\%) X 100/ Hematocrit and is expressed in $\mathrm{gm} / \mathrm{dl}$. Mean Corpuscular Volume (MCV) is calculated by Hematocrit $X$ 10/R.B.C and is expressed in femtoliter. ${ }^{10,11}$ The anthropometric measurement was assessed for calculation of the BMI. The height of students was measured by measuring tape in centimeters, which converted to meters and weight of students were measured in $\mathrm{kg}$ by digital scale [height $(\mathrm{m})^{2}$ and weight $(\mathrm{kg})$ ], according to recommendations of SI unit. Participants of the study were classified into groups; underweight, normal, overweight and obese on the basis of WHO criteria ${ }^{12}$ and considered as an independent of age and sex. As it is considered as marker of nutritional status of adolescents. ${ }^{13}$

$\mathrm{BMI}=$ Weight/ Height $\left(\mathrm{Kg} /\right.$ meters $\left.^{2}\right)$.

The collected data was entered in Microsoft excel \& analyzed by using Statistical Package for Social Sciences (SPSS) version 22.0. The qualitative variables were expressed as Frequency and percentages (\%). The quantitative gathered data were expressed as mean and standard deviation $( \pm)$. The post stratification Chi-Square test was applied with confidence level 95\% and having significant $(p$-value $<0.05)$ and non-significant $(p$-value $>0.05)$ values.

\section{RESULTS}

Table-I to II it was seen that the mean and the standard deviation of age in study participants was $20.35 \pm 1.69$ years. The mean and the standard deviation of height, weight, and BMI were $2.70 \pm 0.30$ in meters, $61.92 \pm 10.75$ in $\mathrm{kg}$ and $23.04 \pm 3.68$ respectively. The mean and the standard deviation of Hemoglobin, $\mathrm{MCH}$, MCV, MCHC and Red Cell Distribution Width (\%) were $13.29 \pm 2.06,26.89 \pm 3.89,80.66 \pm 8.48$, $32.90 \pm 2.67$ and $42.80 \pm 21.84$ respectively. Table-I to III: shows the comparison of red blood cell indices of study participants for different categories of $\mathrm{BMI}$ and it was seen that only $\mathrm{MCH}\left(\mathrm{X}^{2}=28.278\right.$, $\mathrm{p}<0.001)$ and $\mathrm{MCHC}\left(\mathrm{X}^{2}=15.659, \mathrm{p}<0.016\right)$ were statistically significantly different from each other. For $\mathrm{MCH}$, a majority of those were underweight or obese had a low level of hemoglobin $(55.0 \%$ and $44.4 \%$ respectively) whereas a majority of those who had normal weight or were overweight had a normal level of hemoglobin $(60.4 \%$ and $67.1 \%$ respectively). For MCHC, a majority of those were underweight, normal weight or overweight had a normal level of hemoglobin $(61.7 \%, 55.6 \%$ and $60.8 \%$ respectively) whereas a majority of those who were obese had a low level of hemoglobin (44.4\%).

\begin{tabular}{|l|c|}
\hline \multicolumn{1}{|c|}{ Classification } & Values of BMI(kg/m $\left.{ }^{2}\right)$ \\
\hline Under weight & $<18.5 \mathrm{~kg} / \mathrm{m}^{2}$ \\
\hline Normal & 18.5 to $24.99 \mathrm{~kg} / \mathrm{m}^{2}$ \\
\hline Over weight & 25 to $29.99 \mathrm{~kg} / \mathrm{m}^{2}$ \\
\hline Obese & $>30 \mathrm{~kg} / \mathrm{m}^{2}$ \\
\hline
\end{tabular}

Table-I. Levels of BMI according to WHO criteria.

\begin{tabular}{|l|c|c|}
\hline \multicolumn{1}{|c|}{ Variables $(\mathbf{n = 5 0 0 )}$} & Mean & 土 S.D. \\
\hline Age $($ Years $)$ & 20.35 & \pm 1.69 \\
\hline Height $(\mathrm{m})$ & 2.70 & \pm 0.30 \\
\hline Weight $(\mathrm{kg})$ & 61.92 & \pm 10.75 \\
\hline BMI $\left(\mathrm{Kg} / \mathrm{m}^{2}\right)$ & 23.04 & \pm 3.68 \\
\hline Hemoglobin & 13.29 & \pm 2.06 \\
\hline MCH & 26.89 & \pm 3.89 \\
\hline MCV & 80.66 & \pm 8.48 \\
\hline MCHC & 32.90 & \pm 2.67 \\
\hline Red Cell Distribution Width (\%) & 42.80 & \pm 21.84 \\
\hline
\end{tabular}

Table-I. Evaluation of descriptive statistics of the studied population. $(n=500)$.

\section{DISCUSSION}

Health of Human body can be assessed by using various parameters like using labs (biochemically) or using anthropometric measurements, etc. Body mass index (BMI) and Hemoglobin ( $\mathrm{Hb} \%$ ) concentration are some of the most popularly used parameters as to evaluate the human body health. ${ }^{14}$ The present research was done in adolescent's students as to study the association of body mass index (BMI) to hemoglobin ( $\mathrm{Hb} \%$ ) $\&$ red blood cell (erythrocytes) indices. This study consists of 500 students in which mean age was $20.35 \pm 1.69$ and mean body mass index (BMI) was $23.04 \pm 3.68$. 


\begin{tabular}{|c|c|c|c|c|}
\hline Variable $(n=500)$ & \multicolumn{4}{|c|}{ BMI } \\
\hline & Underweight & Normal Weight & Overweight & Obese \\
\hline & Frequency (\%) & Frequency (\%) & Frequency (\%) & Frequency (\%) \\
\hline \multicolumn{5}{|c|}{ Hemoglobin Level } \\
\hline Low & $23(38.3 \%)$ & $111(38.5 \%)$ & $45(31.5 \%)$ & $3(33.3 \%)$ \\
\hline Normal & $35(58.3 \%)$ & $168(58.3 \%)$ & $96(67.1 \%)$ & $6(66.7 \%)$ \\
\hline P-Value & \multicolumn{4}{|c|}{$>0.65$} \\
\hline \multicolumn{5}{|c|}{$\mathrm{MCH}$} \\
\hline Low & $33(55.0 \%)$ & $108(37.5 \%)$ & $45(31.5 \%)$ & $4(44.4 \%)$ \\
\hline Normal & $26(43.3 \%)$ & $174(60.4 \%)$ & $96(67.1 \%)$ & $3(33.3 \%)$ \\
\hline Low & $24(40.0 \%)$ & $110(38.2 \%)$ & $44(30.8 \%)$ & $5(55.6 \%)$ \\
\hline Normal & $36(60.0 \%)$ & $177(61.5 \%)$ & $99(69.2 \%)$ & $4(44.4 \%)$ \\
\hline High & Nil & $1(0.3 \%)$ & Nil & Nil \\
\hline P-Value & \multicolumn{4}{|c|}{$>0.557$} \\
\hline \multicolumn{5}{|c|}{ MCHC } \\
\hline Low & $22(36.7 \%)$ & $114(39.6 \%)$ & $55(38.5 \%)$ & $4(44.4 \%)$ \\
\hline Normal & $37(61.7 \%)$ & $160(55.6 \%)$ & $87(60.8 \%)$ & $3(33.3 \%)$ \\
\hline High & $1(1.7 \%)$ & $14(4.9 \%)$ & & $2(22.2 \%)$ \\
\hline P-Value & \multicolumn{4}{|c|}{$<0.016$} \\
\hline
\end{tabular}

In our study, there were significant associations $\mathrm{MCH} \quad(p<0.001)$ and MCHC $(p<0.016)$ in comparison of red blood cell indices of study participants to different categories of body mass index (BMI). Awad $\mathrm{KM}$ et al. had observed no significant association $(p>0.001)$ of $\mathrm{MCH}$ and MCHC compared to different categories of body mass index (BMI) in his study ${ }^{7}$ so this result is against to our findings. In our study, there were no significant association ( $p>0.001$ ) between $\mathrm{Hb} \%$, MCV \& RDW\% to different categories of body mass index. Iranian and Indian study had observed that body mass index have no significant $(p>0.001)$ association with hemoglobin ( $\mathrm{Hb} \%$ ) level \& MCV, so it that supports our results. ${ }^{15,16}$ As body mass index (BMI) is increases, hemoglobin ( $\mathrm{Hb} \%)$ level decreases in the adolescents students like that results were observed in study this inverse association between high BMI or obesity and anemia is due to increase intake of high caloric junk foods. ${ }^{7,17}$ The coexistence of overweight or obesity and anemia could be result of the energy dense foods consumption on regular bases as these are poor in iron content or it occurs due to poor iron absorption from gut and /or poor utilization that may occur due to chronic inflammation. ${ }^{18}$ Iranian study was observed also that higher prevalence of anemia (iron deficiency) in students with high BMl. ${ }^{19}$ Two other studies done in Indian medical adolescents students, they had observed no significant $(p>0.001)$ association between body mass index with hemoglobin level, that supports our study finding..$^{20,21}$ Overweight and obesity or high BMI is characterized by chronic, low-grade, systemic inflammation, that leads to anemia of chronic disease ${ }^{15}$ or high $\mathrm{BMI}$ is 
associated with inflammation (sub-clinical) which is responsible for the development of anemia. ${ }^{7}$ Many researchers had observed that anemia had directly association with physical inactivity or lack of exercise, lack of extracurricular activities and generalized obesity. ${ }^{22,23,24}$ Anemia mainly affects the physical performance or extracurricular activities, school or college performance, daily attendants in classes, difficulty in concentration in studies, which ultimately distracts the normal health and socioeconomic status. ${ }^{23,25}$ The present study was having limited number of participants and source of funding, so in future this should be on large scale including gender based study, status (class) based study and laboratorial test like ESR, CRP, FERRITIN level and hemoglobin electrophoresis should be done, as to achieve the cause of anemia in participants.

\section{CONCLUSION}

It was seen that the comparison of $\mathrm{Hb} \%, \mathrm{MCV}$ \& RDW had no significant association $(p>0.001)$, while $\mathrm{MCH}(p<0.001)$ and $\mathrm{MCHC}(p=0.016)$ were statistically significantly association with different categories of Body Mass Index in this study.

\section{Conflict of Interest}

Author has no conflict of interest in this study.

\section{Acknowledgment}

The author will be thanking to the study volunteers for their participation.

\section{Source of Funding}

This study was funded by the Baqai Medical University Karachi, Pakistan.

\section{Copyright@ 15 Apr, 2020.}

\section{REFERENCE}

1. World Health Organization, health definition, 1948; 2:100.

2. World Health Organization. Programming for adolescent health and development. WHO Technical Report Series No. 886. Geneva: World Health Organization; 1999. p. 1.
3. Eknoyan, Garabed (2007). "Adolphe Quetelet (17961874)-the average man and indices of obesity". Nephrology Dialysis Transplantation. 23 (1): 47-51. PMID $17890752 \quad$ (https://www.ncbi.nlm.nih.gov/ pubmed/17890752).doi:10.1093/ndt/gfm517 (https:// doi.org/10.1093\%2Fndt\%2Fgfm517).

4. James PT, Leach R, Kalmar E, Shayeghi M. The worldwide obesity epidemic. Obes Res 2001; 9(S11):228S-33S.

5. World Health Organization (WHO). Global Database. Body mass index classification [Internate]. 2018. Available from: http://apps.who.int/bmi/index.jsp?intro pages=intro_3.htm1.

6. Renew bariatrics. Report: 2018. Obesity Rates BY Country -2017 top 10 Most Obese Countries (July $1^{\text {st }}$, Obese Bariatrics News; (July 2017).

7. Awad KM et al. Relationship b/w obesity, physical activity, sleeping hours and red blood cell parameters in adult Sudanese population. Ann Med Physiol. 2019; 3(2):21-26.

8. Khan Z, Nawaz M, Khan A, Bacha U. Hemoglobin, red blood cell count, hematocrit and derived parameters for diagnosing anemia in elderly males. Proceedings of the Pakistan Academy of Sciences. 2013;50(3):21726.

9. Hajar Adib Rad, Sayed Ali Asghar Sefidgar, ${ }^{1}$ Ahmad Tamadoni, ${ }^{2}$ Sadegh Sedaghat, ${ }^{3}$ Fatemeh Bakouei et al. Obesity and iron-deficiency anemia in women of reproductive age in Northern Iran. J Educ Health Promot. 2019; 8: 115.

10. Wintrobe, M. M. Clinical hematology, 6th ed. Lea and Febiger, Philadelphia, USA (1967).

11. Diem, K \& L. Clenter. Scientific Tables, 7th ed. Geigy Pharmaceuticals, Basel, Switzerland (1970).

12. World Health Organization. Obesity and overweight (Fact Sheet).Geneva: World Health Organization. Obesity and Overweight (Fact Sheet). 2015 Geneva. Available at:http://www.who. int/mediacenter/factsheets/ fs311/en/index.html (last accessed on April 12, 2015).

13. Ajay Kumar Agarwal1, Ghanshyam Das Katiyar2, Syed Esam Mahmood3, Swati Khan1, Mahendra Sharma1. A cross sectional study of association of anaemia with $\mathrm{BMI}$ in medical and paramedical students. Int $\mathrm{J}$ Community Med Public Health. 2017 Dec; 4(12):46974701.

14. Maishnam Rustam Singh, Karnajit Mangang2. Anaemia and body mass index (BMI) of fisherwomen inhabiting in Karang Island of Loktak Lake, Manipur (India). Euras J Anthropol. 2012; 3(2):47-53. 
15. Akram ghadiri-anari, 1 narjes nazemian, 1 and hassanali vahedian-ardakani2. Association of body mass index with hemoglobin concentration and iron parameters in Iranian population ISRN Hematology, Volume 2014, Article ID 525312, 3 pages. http://dx.doi. org/10.1155/2014/525312.

16. Namita, Ranjan DP. A cross-sectional study of association between hemoglobin level and body mass index among adolescent age group. Natl J Physiol Pharm Pharmacol 2019; 9(8):746-750.

17. Nead KG, Halterman JS, Kaczorowski JM, Auinger P, Weitzman M. Overweight children and adolescents: $A$ risk group for iron deficiency. Pediatrics 2004; 114:1048.

18. Moayeri H, Bidad K, Zadhoush S, Gholami N, Anari $S$. Increasing prevalence of iron deficiency in overweight and obese children and adolescents (Tehran adolescent obesity study). Eur J Pediatr 2006; 165:813-4.

19. Saxena Y, Shrivastava A, Saxena V. Effect of gender on correlation of anaemia with body mass index in medical students. Indian J Physiol Pharmacol 2011; 55:364-9.

20. Acharya S, Patnaik M, Mishra SP, Panigrahi AK. Correlation of hemoglobin versus body mass index and body fat in young adult female medical students. Natl J Physiol Pharm Pharmacol 2018; 8:1371-3.
21. Ausk KJ, loannou GN. Is obesity associated with anemia of chronic disease? A population-based study. Obesity (Silver Spring) 2008 Oct; 16(10):235661. PMID: 18719644 DOI: 10.1038/oby.2008.353.

22. Qin Y, Melse-Boonstra A, Pan X, Yuan B, Dai Y, Zhao J, Zimmermann MB, Kok FJ, Zhou M, Shi Z. Anemia in relation to body mass index and waist circumference among Chinese women. Nutr J. 2013 Jan 11; 12:10. PMID: 23311667 DOI: 10.1186/1475-2891-12-10.

23. Cepeda-Lopez AC, Osendarp SJ, Melse-Boonstra A, Aeberli I, Gonzalez-Salazar F, Feskens E, Villalpando $S$, Zimmermann MB. Sharply higher rates of iron deficiency in obese Mexican women and children are predicted by obesity-related inflammation rather than by differences in dietary iron intake. Am J Clin Nutr. 2011 May; 93(5):975-83. PMID: 21411619 DOI: 10.3945/ajen.110.005439.

24. Alaoddolehei $\mathrm{H}$, Sadighian F. Microcytic anemia in Babolian 14-18y old girls, 1998, Journal of babol University of medical sciences. 2000; 1:49-52.

25. Sadighian F, Alaoddolehei H, Sajjida P, Kalantari N, Khafri S. Body mass index and blood cell indices in students of paramedical faculty, Babol University of Medical Sciences, Iran J Health Sci. 2016; 4(4): 34-40.

\begin{tabular}{|c|c|c|c|}
\hline \multicolumn{4}{|c|}{ AUTHORSHIP AND CONTRIBUTION DECLARATION } \\
\hline Sr. \# & Author(s) Full Name & Contribution to the paper & Author(s) Signature \\
\hline 1 & Saleem Ullah Abro & $\begin{array}{l}\text { Data collection, Main } \\
\text { investigator. }\end{array}$ & 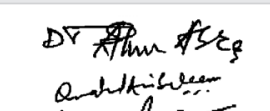 \\
\hline 3 & Amna Begum & Proof reading, Drafting. & Davm Agles \\
\hline 4 & Sarah Azhar & $\begin{array}{l}\text { Proof reading, Lab technical } \\
\text { facilitation. }\end{array}$ & Aubes \\
\hline 6 & & & \\
\hline
\end{tabular}

